\author{
канд. техн. наук. В.M. Баланюк / V.M. Balanyuk, Ph.D. ${ }^{a}$ \\ а) Львовский государственной университет безопасности жизнедеятельности / Lviv State University of Life Safety \\ *Автор-корреспондент / Corresponding author: bagr33@ukr.net
}

\title{
Повышение огнетушащей эффективности бинарных газоаэрозольных смесей ударными волнами
}

\author{
The Increase of Fire Extinguishing Efficiency of Gas-Aerosol Binary Mixture Using Shock Waves \\ Zwiększenie skuteczności gaśniczej binarnych mieszanin gazowo-aerozolowych za pomocą \\ fal uderzeniowych
}

\begin{abstract}
АННОТАЦИЯ
Цель: Определение огнетушашей эффективности комбинированных тернарных огнетушаших систем, содержаших огнетушаший аэрозоль, газы $\mathrm{CO}_{2}\left(\mathrm{~N}_{2}\right)$ при действии ударных волн на диффузионное пламя н-гептана в их среде и выявление возможного механизма тушения ими.

Методы: Для определения возможности тушения диффузионного пламени н-гептана, комбинированным действием газов СО 2 или $\mathrm{N}_{2}$, аэрозоля и ударной волны, которая возникает при взрыве пиротехнического заряда, была оборудована установка в виде камеры объемом 0,5 м³, в которой размешен генератор ударных волн, а на расстоянии 1,75 м от него - тигель с н-гептаном. Газ подавали через газовый счетчик. Измерение давления в фронте ударной волны осушествляли с помошью датчика давления и температуры ВMP-180 для контроллера Аrduino, работа которого основана на пьезорезисторном принципе. Съемка процесса тушения комбинированным действием аэрозоля, газов СО 2 и $\mathrm{N}_{2}$ и ударной волной была проведена с помошью камеры Nikkon 1j4 с возможностью получения кадров со скоростью 1200 кадров в секунду. Результаты: В работе теоретически обоснованы и экспериментально подтверждены научные аспекты повышения огнетушашей эффективности газоаэрозольной смеси, которые заключаются в том, что комбинированное действие на пламя н-гептана, серии ударных волн, газов СО 2 или $\mathrm{N}_{2}$, в смеси с аэрозолем в камере приводит к значительному повышению огнетушашей эффективности такой системы. При этом определено, что огнетушашие концентрации аэрозоля уменьшаются в 8 раз, а газов в бинарной смеси с аэрозолем, в 4,6 раза для СО 2 , и в 4 раза для $\mathrm{N}_{2}$ относительно их индивидуальных огнетушаших концентраций при воздействии на диффузионное пламя н-гептана серии из 3-х ударных волн с частотой 10 Гц и мошности всего в 240 Па

Вывод: Экспериментально определены особенности тушения диффузионного пламени н-гептана в условиях специальной камеры, предложенной комбинированной огнетушашей тернарной системой, которые заключаются в том, что время начала фрагментации значительно уменьшается после прохождения серии ударных волн и пламя при этом отрывается и диспергируется при значительно меньших концентрациях смеси аэрозоля с газом, что приводит к более быстрому тушению.
\end{abstract}

Ключевые слова: пожар, ударная волна, газовое, аэрозольное пожаротушение, огнетушашая концентрация

Вид статьи: оригинальная научная статья

Принята: 10.04.2017; Рецензирована: 06.06.2017; Опубликована: 30.06.2017;

Эту статью наградил Редакционный Совет;

Просим ссылаться на статью следуюшим образом: BiTP Vol. 46 Issue 2, 2017, pp. 72-86, doi: 10.12845/bitp.46.2.2017.5;

Настояшая статья находится в открытом доступе и распространяется в соответствии с лицензией CC BY-NC-SA 4.0

(https://creativecommons.org/licenses/by-nc-sa/4.0/).

\begin{abstract}
Objective: Determination of the n-heptane diffusion flame-extinguishing efficiency of the combined method which uses a fire extinguishing aerosol, $\mathrm{CO}_{2}$ gases $\left(\mathrm{N}_{2}\right)$ and the simultaneous impact in their environment of shock waves. The identification of a possible extinguishing mechanism for this method.

Methods: In order to determine the possibility of extinguishing the diffusion flame of $\mathrm{n}$-heptane by the combined use of $\mathrm{CO}_{2}$ or $\mathrm{N}_{2}$ gases, aerosol and the shock wave created by the explosion of the pyrotechnic charge, an experimental chamber was set up with a volume of $0.5 \mathrm{~m}^{3}$. Inside the chamber, a shock wave generator was installed, and a crucible with $\mathrm{n}$-heptane was placed at a distance of $1.75 \mathrm{~m}$ from it. The gas was fed to the chamber through a gas meter. The pressure in front of the shock wave was measured with a BMP-180 pressure and temperature sensor for the Arduino controller, which operates on a piezoresistive basis. The photographic documentation of the extinguishing process by the combined action of aerosol, $\mathrm{CO}_{2}$ and $\mathrm{N}_{2}$ gases, and a shock wave was done using the Nikkon $1 \mathrm{j} 4$ camera with a frame rate of 1200 frames per second.
\end{abstract}


Results: The scientific aspects of the increase in the fire-extinguishing efficiency of the gas-aerosol mixture are theoretically substantiated and experimentally confirmed in this paper. Accordingly, the combined impact of a series of shock waves and $\mathrm{CO}_{2}$ or $\mathrm{N}_{2}$ gases mixed with aerosol on the flame of $n$-heptane inside a chamber, leads to a significant increase in the extinguishing efficiency of such a method. It has also been demonstrated that the extinguishing aerosol concentrations decrease 8 times, and the gases concentration in the binary mixture with the aerosol decreases 4,6 times for $\mathrm{CO}_{2}$, and 4 times for $\mathrm{N}_{2}$ in a relation to their individual extinguishing concentrations when the diffusion flame of the $n$-heptane is exposed to a series of 3 shock waves with a frequency of $10 \mathrm{~Hz}$ and a total power of only $240 \mathrm{~Pa}$

Conclusion: The characteristics of extinguishing the diffusion flame of $n$-heptane under the conditions of a special chamber were determined experimentally using the proposed combined extinguishing method. The tests have shown that the time for the onset of fragmentation decreases significantly after exposure to a series of shock waves, and the flame is then detached and dispersed at much lower concentrations of aerosol and gas mixture, which leads to faster extinguishing. Keywords: fire, shock wave, gas, aerosol fire extinguishing, fire extinguishing concentration Type of article: original research article

Received: 10.04.2017; Reviewed: 06.06.2017; Published: 30.06.2017;

The article was recognised by the Editorial Committee

Please cite as: BiTP Vol. 46 Issue 2, 2017, pp. 72-86, doi: 10.12845/bitp.46.2.2017.5;

This is an open access article under the CC BY-NC-SA 4.0 license (https://creativecommons.org/licenses/by-nc-sa/4.0/).

\begin{abstract}
ABSTRAKT
Cel: Określenie skuteczności gaśniczej połączonych trójskładnikowych systemów gaśniczych wykorzystujących aerozol gaśniczy, gazy $\mathrm{CO}_{2}\left(\mathrm{~N}_{2}\right)$ oraz jednoczesne oddziaływanie w ich środowisku fal uderzeniowych w gaszeniu płomienia dyfuzyjnego n-heptanu. Wyznaczenie możliwego mechanizmu gaśniczego omawianego sposobu. Metody: W celu zbadania możliwości gaszenia płomienia dyfuzyjnego n-heptanu przy jednoczesnym zastosowaniu gazów $\mathrm{CO}_{2}$ lub $\mathrm{N}_{2}$, aerozolu i fali uderzeniowej powstającej wskutek wybuchu ładunku pirotechnicznego zbudowane zostało stanowisko badawcze w postaci komory o objętości 0,5 m³. W komorze umieszczono generator fal uderzeniowych, a w odległości 1,75 m od niego - tygiel z n-heptanem. Gaz dostarczany był do komory poprzez licznik gazowy. Pomiary ciśnienia na froncie fali uderzeniowej były wykonywane za pomocą czujników ciśnienia i temperatury BMP-180 kontrolera Arduino, działającego na zasadzie piezorezystancji. Dokumentacja zdjęciowa procesu gaśniczego z jednoczesnym działaniem aerozolu, gazów $\mathrm{CO}_{2}$ i $\mathrm{N}_{2}$ oraz falą uderzeniową była zrealizowana za pomocą aparatu Nikon 1j4, umożliwiającego rejestrację obrazu z szybkością 1200 klatek na sekundę

Wyniki: W artykule w sposób teoretyczny i eksperymentalny potwierdzone zostały aspekty naukowe zwiększenia skuteczności gaśniczej mieszaniny gazów i aerozolu. Zgodnie z nimi połączone oddziaływanie na płomień n-heptanu serii fal uderzeniowych oraz gazów $\mathrm{CO}_{2}$ lub $\mathrm{N}_{2}$ zmieszanych z aerozolem w komorze badawczej pozwala na znaczne zwiększenie skuteczności gaśniczej tej metody. Wykazano również, że przy działaniu na płomień dyfuzyjny n-heptanu serii 3 fal uderzeniowych o częstotliwości $10 \mathrm{~Hz}$ i mocy całkowitej 240 Pa stężenie gaśnicze aerozolu zmniejsza się ośmiokrotnie, a stężenie gazów w binarnej mieszaninie z aerozolem w przypadku $\mathrm{CO}_{2}$ zmniejsza się o 4,6 razy, a dla $\mathrm{N}_{2} \mathrm{O} 4$ razy w stosunku do stężeń gaśniczych tych substancji z osobna.

Wniosek: W drodze eksperymentu określono właściwości gaszenia płomienia dyfuzyjnego n-heptanu w warunkach specjalnej komory za pomocą zaproponowanej potrójnej metody. Badania wykazały, że po przejściu serii fal uderzeniowych czas rozpoczęcia fragmentaryzacji ulega znaczącemu skróceniu. Jednocześnie płomień odrywa się i dysperguje przy dużo niższych stężeniach mieszaniny aerozolu z gazem, umożliwiając szybsze gaszenie.
\end{abstract}

Słowa kluczowe: pożar, fala uderzeniowa, gaszenie gazem, gaszenie aerozolem, stężenie środka gaśniczego

Typ artykułu: oryginalny artykuł naukowy

Przyjęty: 10.04.2017; Zrecenzowany: 06.06.2017; Opublikowany: 30.06.2017;

Artykuł został wyróżniony przez Komitet Redakcyjny;

roszę cytować: BiTP Vol. 46 Issue 2, 2017, pp. 72-86, doi: 10.12845/bitp.46.2.2017.5;

Artykuł udostępniany na licencji CC BY-NC-SA 4.0 (https://creativecommons.org/licenses/by-nc-sa/4.0/).

\section{Вступление}

В практике пожаротушения в закрытых объемах, одним из наиболее эффективных, является способ тушения пожара, при котором во всем защищаемом объеме создается среда, не поддерживающая процесс горения. Для этого в качестве объемных огнетушащих веществ используются газовые инертные разбавители, огнетушащие аэрозоли или порошки и, реже, химически активные галогенуглеводороды - хладоны. Однако, инертные разбавители имеют низкую огнетушащую способность, а огнетушащие порошки быстро седиментируют и, соответственно, их огнетушащая кон- центрация исчезает уже на 60-70 секундах после применения. Хладоны способствуют разрушению озонового слоя Земли и поэтому международные документы запрещают производство или использование некоторых из них [1]. Современные аэрозольные средства пожаротушения по основным технико-экономическим показателям (высокая огнетушащая способность, автономность, возможность автоматического приведения в действие, простота в эксплуатации, минимальные убытки при применении) превосходят все средства, ранее используемые для тушения пожара. При этом в двухфазной системе аэрозоля газообразный компонент - как правило - это смесь инертных газов, ко- 
торая не поддерживает горения, а свежеобразованные высокодисперсные твердые частицы имеют высокую огнетушащую способность благодаря их небольшим размерам (до 50 мкм). Несмотря на все положительные качества, огнетушащие аэрозоли имеют также и ряд недостатков значительно уменьшают оптическую проницаемость среды. При сгорании аерозольобразующего состава образуется форс пламени. В случае негерметичности, их концентрация может быстро и значительно уменьшаться.

Кроме этого, существует ряд объектов, на которых необходимо применять огнетушащие средства, обладающие высокой эффективностью и скоростю тушения с целью предупреждения увеличения размеров пожара и соответственно убытков от него. В перечень таких объектов входят: резервуары с горючими жидкостями и газами, компрессорные и насосные станции, машинные залы, электрощитовые, трансформаторные подстанции, химические предприятия, склады легковоспламеняющихся и горючих жидкостей, объемы технологических аппаратов, резервуары под давлением, котельные, склады и места хранения боеприпасов, моторные отсеки боевой техники (танки, бронетранспортеры, боевые машины, морские судна). Особенно проблематично тушить пожары горючих жидкостей в разливах, в резервуарах и труднодоступных местах, с большим количеством коммуникаций, значительной пожарной нагрузкой, затрудненным доступом и возможным возникновением длительно существующих мощных источников зажигания. Отдельно следует отметить актуальность предложенного способа тушения для быстрой ликвидации пожаров в условиях боевых действий, особенно связанных с действием зажигательных средств или ликвидации чрезвычайных ситуаций - землетрясений, наводнений, ураганов, когда развертывание и применение обычных сил и средств затруднено, а то и невозможно.

\section{Анализ результатов последних исследований}

Известно, что на данный момент тушение пожаров на выше перечисленных объектах требует значительного времени, количества сил и средств. Кроме того, пожары, возникающие на объектах нефтегазовой, химической, деревообрабатывающей промышленности, характерны стремительным развитием, сложным и затяжным тушением, значительными затратами материальных ресурсов и времени на тушение, а также нанесением значительных убытков и загрязнениями среды. Так, например, пожары, которые возникли в Кувейте в 1990-1992 годах, [2] и сразу не были ликвидированы из-за нехватки средств и сил, стали источником выброса в атмосферу десятков тысяч тонн токсичных веществ, уровень которых в атмосфере в зоне локализации пожаров значительно увеличился.

В целом пожары на объектах нефтеперерабатывающей отрасли, в частности на нефтехранилищах, как правило, с первых минут приобретают значительные масштабы, что можно увидеть на примере крупнейших пожаров произошедших в мире.
Так утром, 11 декабря 2005 года [3], произошел ряд взрывов на складе хранения нефти, в Хэмел Хэмпстед, графство Хартфордшир, Великобритания. В результате взрыва в одном из резервуаров начался пожар, охвативший часть резервуарного парка. Это был самий большой пожар в Европе за 60 лет в мирное время. Более 40 человек получили ранения. В непосредственной близости от нефтебазы были значительно разрушены объекты коммерческой и жилой недвижимости. Пожар длился в течение нескольких дней, уничтожив при этом большую часть резервуарного парка. В целом, было эвакуировано около 2000 домов, а 92 соседних предприятий пострадали от этого, крупнейшего в Европе пожара. Другой крупный пожар [4] произошол в Украине на нефтебазе в с. Крячки, Киевской области, когда 8 июня 2015 года, в 17:29 загорелся резервуар с топливом объемом 800 м $^{3}$ (650 тонн) и через короткое время пламя охватило 4 резервуара. Пожар начали тушить 9 июня, при этом ночью, когда огонь охватил уже 8 резервуаров с горючим. В середине дня началось временное отселение граждан из двухкилометровой зоны от границы пожара. По состоянию на 17:00 на нефтебазе продолжали гореть лишь три резервуара - один с маслом, два с горючим. Остальные резервуары были разрушены. К ликвидации пожара были привлечены около 300 спасателей и 45 единиц техники. До конца суток 9 июня возгорание удалось локализовать. 10 июня, в 5:30 на нефтебазе произошел очередной взрыв. В течение дня, 10 июня нефтепродукты продолжали выгорать. В 22:10, 10.06.15 произошел еще один взрыв. Пожарные провели четыре пенные атаки. В 10:15 11 июня произошел еще один взрыв, в результате которого взорвались две емкости с топливом 800 куб. м. 12 июня пожар постепенно угасал, догорал один большой резервуар. 13 июня снова загорелся один резервуар, который продолжал гореть. До вечера и утра 14-го резервуар выгорел, после чего осуществлялся мониторинг пожарной стихии спасателями. Последние признаки горения (фитилирования) резервуаров исчезли вечером 16 июня. Принимая во внимание примеры этих пожаров, можно сделать вывод, что в настоящее время отсутствуют средства быстрого и эффективного тушения таких пожаров, что приводит к описаным выше катастрофическим последствиям.

В общем, как известно, пожары горючих жидкостей в резервуарах обычно начинаются со взрыва. При этом такие параметры пожара, как температура, скорость распространения пламени, интенсивность газообмена достигают максимальных показателей с первых моментов развития пожара и могут сохранять указанные параметры длительное время, несмотря на подачу огнетушащих средств. При интенсивном горении, особенно горючих жидкостей в разливе и в резервуаре, нередко огнетушащее средство под действием конвективных потоков относится от места горения так и не проникнув в зону горения. Отдельно следует отметить вопрос стоимости тушения и времени, которое для некоторых сложных пожаров составляет до нескольких дней, а стоимость измеряется внушительными суммами. Таким образом, еще раз можно сделать вывод о недостаточной эффективности существующих средств тушения, предназначенных для тушения данного типа пожаров. 
Повышать эффективность существующих средств тушения исследователи предлагают разными путями, наиболее перспективные из них те, которые обеспечивают высокую огнетушащую эффективность с использованием взрыва и заключаются, например, в распылении огнетушащего вещества взрывом [5]. Авторы работы [5] указывают, что огнетушащий эффект от взрыва и образования тонкраспыленной воды достигается лишь при образовании сильных одиночных ударных волн, которые подавляют горение, но для слабых одиночных ударных волн значительного огнетушащего эффекта не наблюдали. Подобный способ тушения исследовали в работе [6]. В данной работе авторы для достижения огнетушащего эффекта предлагают взрывать емкости с большим количеством воды от 600 до 1500 л, при этом авторы пришли к существенному выводу, что решающее влияние на свойства детонации взрывного заряда и на интенсивность ударной волны имеет воздух, который втягивается вверх.

Авторы [7] с целью тушения пожаров углеводородов предлагают применять импульсные огнетушащие системы, которые обеспечивают подачу дисперсного калия гексацианоферата для тушения. Авторы установили, что минимальная огнетушащая концентрация веществ указанного комбинированного способа составляет $50 \mathrm{r} / \mathrm{M}^{3}$. Недостатком такой системы является то, что дисперсная вода быстро оседает, не обеспечивая длительного времени тушения. В общем, импульсное пожаротушение является перспективным направлением, в котором тоже используется сила взрыва или сжатого газа, но оно имеет ряд недостатков, основной из которых это незначительное время действия огнетушащего вещества на пламя. Кроме этого, недостатком является и то, что на тушение под давлением подается огнетушащее средство, как правило, вода, устройство подачи которого достаточно технически сложное, и струя огнетушащего вещества не имеет достаточной энергии для преодоления значительного расстояния эффективного действия, а также не всегда достигается однородность распыления огнетушащего вещества и равномерное образование огнетушащей концентрации. Исходя из этого можно сделать вывод, что энергия взрыва будет весомой дополнительной огнетушащей составляющей для комбинированого тушения огня.

Таким образом, краткий анализ показал, что в настоящее время поиск эффективных средств тушения, которые обеспечивали бы эффективное, быстрое и недорогое тушение с минимальными материальными потерями от пожара является актуальным. Кроме этого, особенности развития и распространения пожаров на объектах с наличием горючих и легковоспламеняющихся жидкостей приводят к выводу, что для достижения быстрого тушения пожаров таких объектов существующие огнетушащие средства, в частности объемного типа, требуют значительного совершенствования или даже замены на более современные и эффективные средства тушения, которые обеспечивают минимальное время тушения. Использование ударных волн с целью повышения эффективности объемных огнетушащих систем является новым перспективным и надежным способом повышения огнетушащей эффективности комбинированых объемных огнетушащих систем, отвечающие изложенным требованиям.

\section{Изложение основного материала}

Известно, что при сжигании АOC с каждого его грамма образуется 3-5 л газо-аэрозольной смеси, содержащей дисперсные частицы солей калия, натрия [8]. При сгорании $\mathrm{AOC}$ дополнительно образуются также и инертные газы флегматизаторы $-\mathrm{CO}_{2}, \mathrm{~N}_{2}$, водяной пар и др. При взаимодействии этих частиц образуется сложная аэрозольная система, структура которой постоянно меняется во времени $[9,10]$. Так, в момент образования, газо-аэрозольная система состоит из ультрадисперсных частиц солей калия, которые могут формировать структуры с содержанием воды и $\mathrm{CO}_{2}[9,10]$. Такие структуры будут оказывать гораздо более эффективное огнеподавляющее действие благодаря комбинированному действию ингибиторов и флегматизаторов [10]. Дополнительно повысить огнетушащую эффективность аэрозолей и порошков, а также частично нивелировать их недостатки, позволяют добавки инертных газов - флегматизаторов $[11,12,13]$. Из работ $[14,10,15]$ известно, что смеси огнетушащих аэрозолей с газами $\mathrm{CO}_{2}$ и $\mathrm{N}_{2}$ обладают высокой огнетушащей и флегматизирующей концентрацией.

Так, например, смесь огнетушащего аэрозоля, образованного из АОС на основе идитола с добавкой $\mathrm{CO}_{2}$ и $\mathrm{N}_{2}$, обеспечивает огнетушащую эффективность для диффузионного пламени н-гептана, уже при соотношении 15 г/м $\mathrm{M}^{3}$ аэрозоля и 2,5\% газа в условиях испытательной камеры [14]. При этом влияние бинарной смеси приводит к уменьшению температуры диффузионного пламени до $100^{\circ} \mathrm{C}$, что обеспечивает тушение пламени через охлаждение уже при незначительном увеличении концентрации газа [14]. При этом, соотношение азота и аэрозоля являются следующими: концентрации аэрозоля 10 г/ $\mathrm{M}^{3}$ соответствует концентрация $\mathrm{N}_{2}$ В $12,5 \%$, что на 60 \% меньше, чем индивидуальная огнетушащая концентрация самого азота. Бинарные аэрозольно-азотные смеси с позиции пожаротушения являются достаточно перспективными, так как обеспечивают значительную огнетушащую эффективность уже при незначительных концентрациях компонентов. Так, в работе [16] указано, что смеси огнетушащего аэрозоля и газов эффективно тушат и флегматизируют объем, в котором могут находиться даже зажигательные смеси с высокой температурой горения. В работе [17] отмечается, что даже незначительная добавка к газу дисперсного огнетушащего вещества приводит к значительному повышению огнетушащего эффекта такой системы. А в работах [18] определены зависимости огнетушащей концентрации смесей огнетушащего аэрозоля с $\mathrm{AOC}$ на основе идитола от добавок газов $-\mathrm{CO}_{2}$ и $\mathrm{N}_{2}$. В целом получены соотношения совпадающие с результатами работы [19], в которой тоже получено значительное увеличение огнетушащей эффективности тернарной огнетушащей системы $\mathrm{CO}_{2}, \mathrm{~N}_{2}$ и УВ. Из полученных соотношений можно выделить оптимальные эффективные соотношения компонентов бинарных смесей, которые обеспечивают эффективное тушение диффузионного пламени. Так для бинарной смеси 
аэрозоля и $\mathrm{CO}_{2}$ область эффективных концентраций является следующей: А $-7,5$ г/M $\mathrm{M}^{3} \mathrm{CO}_{2}-8 \%$, а с азотом это соотношение составляет A - 10 г/ $\mathrm{M}^{3} \mathrm{~N}_{2}-12 \%$.

Таким образом, как видно из сравнения данных, незначительная добавка газов $\mathrm{CO}_{2}$ и $\mathrm{N}_{2}$ существенно повышает огнетушащую эффективность бинарных аэрозольно-газовых смесей.

Еще одним методом повышения эффективности объемных средств тушения является действие на пламя ударной волны. Так в работе [20] теоретически обоснована и экспериментально установлена высокая эффективность тушения диффузионного пламени н-гептана ударной волной мощностью около 215 Па в камере на расстоянии до 2-х метров. Теоретически обосновано, что возможный механизм тушения заключается в изменении таких параметров, как концентрация реагирующих компонентов в зоне горения, давление, внесение в зону горения дополнительных газовых компонентов, а также резкое снижение температуры газовой среды вокруг пламени. К дальнейшему увеличению эффективности приводит воздействие на пламя серий ударных волн. Так влияние ударных волн при частоте 10 Гц обеспечивает тушение пламени идентичных параметров, но при более низких значениях давления - до $30 \%$ УВ [21]. В работе [22] теоретически обоснована и экспериментально подтверждена возможность значительного повышения огнетушащей эффективности газов $\mathrm{CO}_{2}$ и $\mathrm{N}_{2}$ ударной волной на примере тушения диффузионного пламени н-гептана в камере на расстоянии до 2-х метров. При этом автором [22] экспериментально определено, что огнетушащая концентрация уменьшается в 2,5 раза для $\mathrm{CO}_{2}$ и в 2 раза - для $\mathrm{N}_{2}$ при мощности ударной волны в 180 Па для диффузионного пламени н-гептана. В этой же работе [22 польша 2] автором экспериментально определено, что общим результатом действия ударной волны и огнетушащего газа будет значительное уменьшение времени тушения диффузионного пламени н-гептана, которое в случае с $\mathrm{CO}_{2}$ снижается до 7 раз, а для $\mathrm{N}_{2}$ - до 4,2 раза, в сравнении с временем тушения только ударной волной, которое составляет около 350 мс. Также экспериментально определены особенности тушения диффузионного пламени н-гептана в условиях специальной камеры, предложенной комбинированной огнетушащей системой, которые заключаются в том, что время начала фрагментации пламени значительно уменьшается, что приводит к его более быстрому тушению. Относительно влияния УВ на огнетушащую эффективность аэрозоля, то в работе [23] экспериментально установлено, что действие газовой ударной волны значительно уменьшает огнетушащую концентрацию аэрозольного вещества на расстоянии до 20 см от пиротехнического заряда. Концентрация аэрозольного вещества при этом составляет от 11,4 г/м ${ }^{3}$ на расстоянии 40 сантиметров до 18,8 г/ $\mathrm{M}^{3}$ на расстоянии 280 сантиметров. При частоте ударных волн 8-10 Гц огнетушащая эффективность увеличивается до $26 \%$, уменьшая значение огнетушащей концентрации до 11,4 г/м ${ }^{3}$ на расстоянии 40 сантиметров. Эффективное действие ударной газовой волны при этом увеличится до 280 сантиметров с соответствующей огнетушащей концентрацией 18,8 г/M‥ В другой работе [24] указано, что эффективность рассматриваемого метода тушения зависит от расстояния до очага $L, M$, мощности ударно-акустической волны Ра и массы (концентрации) аэрозоля Ма.

Применение ударной волны является наиболее эффективным при расположении источника УВ на одном уровне с пламенем. Это объясняется том, что при действии УВ сбоку по фронту контакта УВ возникают места с нестойкостями Рихтмаера-Мешкова, которые и становятся причиной фрагментации пламени и его дальнейшего тушения. При этом соответственно минимальная ог-

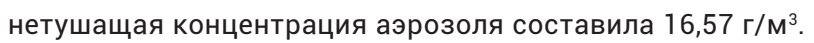
В работе [25] сделан вывод, что применение ударных волн при одновременном тушении аэрозолем является эффективным фактором влияния на огнетушащую эффективность системы: огнетушащий аэрозоль - ударная волна - пламя. Применение ударных волн приводит к задействованию почти всех механизмов огнеподавления, и в результате получаем значительное уменьшение необходимой огнетушащей концентрации огнетушащего аэрозоля,газа или их бинарной смеси. Уменьшение значения огнетушащей концентрации будет обратно пропорционально мощности ударной волны а также будет ограниченное действие в пространстве.

Таким образом влияние УВ на диффузионное пламя в среде бинарной смеси газов и аэрозоля будет обеспечивать одновременно действие многих огнетушащих факторов (таблица 1). Суммарно они должны обеспечивать значительно более высокую огнетушащую эффективность, чем индивидуальные огнетушащие концентрации газов, аэрозоля и огнетушащего давления УВ.

Как видно из таблицы комбинированное действие компонентов тернарной огнетушащей системы обеспечивает тушение с испльзованием почти всех факторов пожаротушения кроме изолирования. Их совокупное действие обеспечит значительную огнетушащую эффективность, что и видно из результатов определения огнетушащей эффективности бинарных систем [14, 15]. Исходя из указанных огнетушащих факторов аэрозоля газов $\mathrm{CO}_{2}$ и $\mathrm{N}_{2}$ и УВ можно сказать, что в указанных диапазонах бинарные смеси будут наиболее эффективны и практичны за счет гармонизации преимуществ каждого из средств тушения и объединения их эксплуатационных преимуществ. Дальнейшее влияние на пламя УВ в их среде приведет к еще большему уменьшению огнетушащих концентраций аэрозоля и газов $\mathrm{CO}_{2}$ и $\mathrm{N}_{2}$. Таким образом, при комбинированном действии тернарной системы огнетушащего аэрозоля системы, газа, и УВ на диффузионное пламя н-гептана будет задействовано одновременно, как говорилось выше, значительное количество факторов (табл. 1). Как видно, тернарная огнетушащая комбинированная система эффективна за счет сочетания таких основных огнетушащих факторов, как ингибирование и охлаждение аэрозолем, разбавление и охлаждение газом разбавителем, отрыв пламени и фрагментация УВ и т.д. (табл. 1.) 
Таблица 1. Огнетушащие факторы комбинированной смеси огнетушащего газа и аэрозоля при воздействии ударных волн Table 1. The factors associated with extinguishing fire with a mixture of fire-extinguishing gas and aerosol exposed to shock waves

\begin{tabular}{|c|c|c|}
\hline $\begin{array}{l}\text { Огнетушащие факторы } \\
\text { аэрозоля / Aerosol-related } \\
\text { fire-extinguishing factors }\end{array}$ & $\begin{array}{c}\text { Огнетушащие факторы газов / } \\
\text { Gas-related fire } \\
\text { extinguishing factors }\end{array}$ & $\begin{array}{c}\text { Огнетушащие факторы УВ / } \\
\text { sW-related fire suppression factors }\end{array}$ \\
\hline $\begin{array}{l}\text { - ингибирование зоны } \\
\text { горения при проникновении } \\
\text { огнетушащего аэрозоля / } \\
\text { the inhibition of the } \\
\text { combustion zone during } \\
\text { the penetration of } \\
\text { fire-extinguishing aerosol } \\
\text { - частичное охлаждение } \\
\text { дисперсными частицами } \\
\text { аэрозоля пламени } \\
\text { в результате их нагрева / } \\
\text { the partial cooling of the } \\
\text { flame with dispersed aerosol } \\
\text { раrticles due to their heating up } \\
\text { - разбавление продуктами } \\
\text { разложения аэрозоля / } \\
\text { the dilution of the } \\
\text { decomposition }\end{array}$ & $\begin{array}{l}\text { - разбавление зоны горения / } \\
\text { dilution of the combustion zone } \\
\text { - увеличения } \\
\text { теплопоглощения } \\
\text { в зоне горения за счет } \\
\text { теплоемкости газа / } \\
\text { increase in the heat absorption } \\
\text { in the combustion zone due } \\
\text { to the heat capacity of the gas } \\
\text { - увеличение концентрации } \\
\text { инертных газов в зоне } \\
\text { горения / the increase in the } \\
\text { сопсеntration of inert gases } \\
\text { in the combustion zone }\end{array}$ & 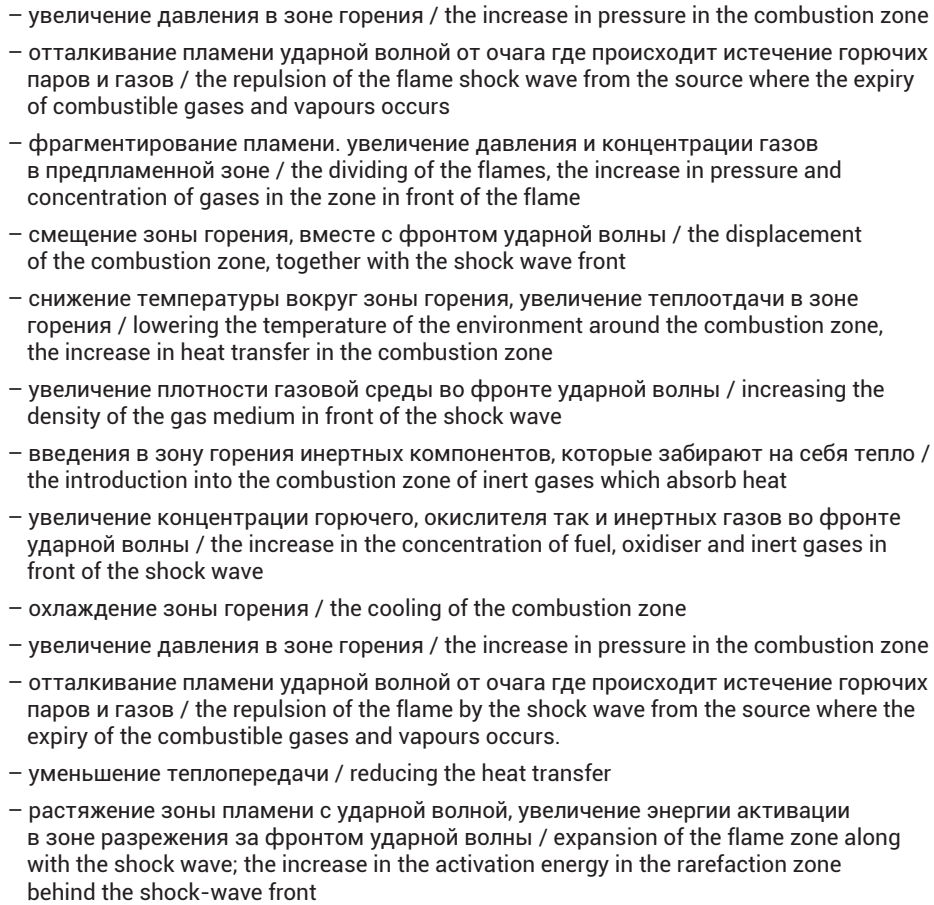 \\
\hline
\end{tabular}

Источник: Собственная разработка.

Source: Own elaboration.

Исходя из указанных результатов анализа огнетушащих факторов и результатов исследований авторов, можно сказать, что комбинированное применение огнетушащего аэрозоля, газа при действии УВ на диффузионное пламя в их среде, приведет к значительному повышению огнетушащей эффективности такой системы. Относительно возможного механизма тушения, то в работе [20] показано начало действия УВ на пламя. При этом, при тушении, пламя отклоняется от тигля на некоторое расстояние, фрагментируется, отрывается и тухнет. В результате проведения эксперимента по определению огнетушащей эффективности самой ударной волны в условиях камеры было установлено, что давление тушения составляет 215 Па в условиях камеры. Процесс тушения ударной волной с давлением около 215 Па описан в работе [20].

Таким образом, результаты эксперимента [20] показали, что огнетушащее действие ударной волны с давлением во фронте в 215 Па обеспечивает тушение пламени н-гептана в условиях специальной камеры. При уменьшении мощности ударной волны до 160 Па и комбинированном применении УВ и газов $\mathrm{CO}_{2}$ и $\mathrm{N}_{2}$ происходит уменьшение огнетушащей концентрации $\mathrm{CO}_{2}$ до 7,5 \%, а $\mathrm{N}_{2}$ - до 15,4 \%. Данные по уменьшению огнетушащей концентрации газов при увеличении давления приведены в таблице 2.

Как видно из таблицы 2 добавление к аэрозолю газов $\mathrm{CO}_{2}$ и $\mathrm{N}_{2}$ приводит к значительному повышению их эф- фективности. При этом, как видим, комбинация 10 г/м ${ }^{3}$ аэрозоля и $6 \% \mathrm{CO}_{2}$ обладает такой же огнетушащей эффективностью, как и при действии УВ с давлением в 150 Па на пламя н-гептана в тигле с диаметром 30 мм. Для огнетушащих систем с содержанием $\mathrm{N}_{2}$ тоже наблюдается значительное увеличение огнетушащей эффективности и для бинарной системы соотношения являются следующими: - аэрозоля 10 г/м³ и $12 \% \mathrm{~N}_{2}$. При действии одинарной УВ с давлением в 240 Па наблюдается снижение концентрации $\mathrm{N}_{2}$ до 17,5 \% от исходной индивидуальной огнетушащей концентрации в 33 \%. При увеличении давления УВ или действии УВ сериями с частотой около 10 Гц на пламя происходит еще большее повышение огнетушащей эффективности тернарной огнетушащей системы УВ + газ + аэрозоль.

Таким образом, учитывая проведенный анализ, по особенностям тушения тернарной системой на основе УВ можно сказать, что экспериментальное определение огнетушащей эффективности такой системы представляет значительный интерес и требует дополнительного исследования.

Кроме этого, на основе проведенного анализа можно утверждать, что в настоящее время не исследована огнетушащая эффективность комбинированных тройных огнетушащих систем, на основе огнетушащего аэрозоля, газа $\mathrm{CO}_{2}\left(\mathrm{~N}_{2}\right)$ и ударных волн. 
Таблица 2. Огнетушащие соотношение газов разбавителей и аэрозоля из АОС на основе идитола без и при воздействии УВ Table 2. The ratio between diluent gases and the aerosol produced from the iditol-based aerosol mixture during the impact of and in the absence of a shock wave

\begin{tabular}{|c|c|c|c|c|c|c|c|}
\hline \multicolumn{8}{|c|}{ Соотношение газов разбавителей и аэрозоля / The ratio of diluent gases to the aerosol } \\
\hline \multicolumn{2}{|c|}{ без УВ / without SW } & \multicolumn{2}{|c|}{ c УB / with SW } & \multicolumn{2}{|c|}{ без УВ / without SW } & \multicolumn{2}{|c|}{ с Ув / with SW } \\
\hline 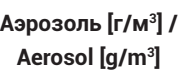 & $\% \mathrm{CO}_{2}$ & $\begin{array}{c}\text { Давление [Па] / } \\
\text { Pressure [Pa] }\end{array}$ & $\% \mathrm{CO}_{2}$ & $\begin{array}{c}\text { Аерозоль }\left[\mathrm{r} / \mathrm{M}^{3}\right] / \\
\text { Aerosol }\left[\mathrm{g} / \mathrm{m}^{3}\right]\end{array}$ & $\% \mathbf{N}_{2}$ & $\begin{array}{c}\text { Давление Па] / } \\
\text { Pressure [Pa] }\end{array}$ & $\% \mathbf{N}_{2}$ \\
\hline 25 & 0 & 0 & 22,8 & 25 & 0 & 0 & 33,4 \\
\hline 20 & 2 & 110 & 17,5 & 20 & 4 & 110 & 27,5 \\
\hline 15 & 2,5 & 130 & 14 & 15 & 8 & 130 & 22,5 \\
\hline 10 & 6 & 150 & 10 & 10 & 12 & 150 & 17,5 \\
\hline 7,5 & 8 & 160 & 7,5 & 7,5 & 15 & 160 & 15 \\
\hline 5 & 14 & 170 & 6 & 5 & 18 & 170 & 12,5 \\
\hline 3,5 & 15 & 180 & 5 & 3,5 & 21 & 180 & 10 \\
\hline 2,5 & 17,5 & 190 & 3,5 & 2,5 & 25 & 190 & 7 \\
\hline 2 & 20 & 200 & 2,5 & 2 & 30 & 200 & 2,2 \\
\hline
\end{tabular}

Источник: Собственная разработка.

Source: Own elaboration.

\section{Цель работы}

Целью работы является определение огнетушащей эффективности комбинированных тернарных огнетушащих смесей, содержащих огнетушащий аэрозоль и газы $\mathrm{CO}_{2}$ $\left(\mathrm{N}_{2}\right)$ при действии ударных волн на диффузионное пламя н-гептана в их среде и выявление возможного механизма тушения ими.

\section{Методы исследований}

С целью подтверждения теоретически обоснованного повышения огнетушащей эффективности комбинированных бинарных газоаэрозольных систем ударной волной за основу была взята экспериментальная методика определения огнетушащей способности УВ автора [22]. При этом использовали химически чистые $(99,9 \%) \mathrm{CO}_{2}$ и N $\mathrm{N}_{2}$. Экспериментальная камера (рис. 3) состояла из: камеры с передней панелью (длина 1980 мм, ширина 485 мм, высота 530 мм) с двумя люками для внесения тиглей, генератора ударных волн и датчика давления и температуры ВMP180 для контроллеров Arduino [26] со временем реакции не более 7,5 мс в нормальном режиме измерения и, дополнительно, воспламенителя АОС. Подачу соответствующей частоты тока на электрические зажигатели пиротехнических зарядов проводили с помощью электронной схемы на основе платы контроллера Arduino, дисплея, переменного резистора изменения времени задержки, кнопки и модуля реле. Воспламенение заряда осуществляли источником тока напряжением около $20 \mathrm{~B}$, которое получали на выходе реле с соответствующей частотой в 10 Гц. Измерение интенсивности теплового потока осуществляли прибором ПТП - 01 с автономным питанием на одинаковом расстоянии в 150 мм от фронта пламени.
Эксперимент проводили следующим образом. В камере устанавливался тигель диаметром 40 мм и глубиной 35 мм с предварительно зажженным за 20 секунд н-гептаном. На расстоянии 1750 мм от генератора ударных волн (рис 4) измеряли его тепловую интенсивность излучения, после чего заполняли камеру газом соответствующей концентрации, поджигали АОС и перемешивали вентилятором образовавшуюся смесь. Потом задействовали генератор ударных волн, пропуская по камере одну или серию ударных волн соответствующей мощности и частоты и фиксировали результат - «тушение», «отказ», «изменения в пламени». После каждой попытки объем камеры продували для следующего опыта. Во время проведения эксперимента, соответствующие состояния тушения пламени были засняты камерой Nikon 1 J4 с частотой съемки 1200 кадров. Потом была проведена раскадровка видеоролика.

\section{Результаты}

Сначала была определена огнетушащая эффективность УВ при тушении диффузионного пламени н-гептана (ДПГ) с тепловой мощностю излучения 14 кВт/м ${ }^{2}$ (диаметр тигля 100 мм). Для этого была использована методика [20] и установлено, что огнетушащее давление во фронте УВ при этом составляет 335 Па. Далее установлено влияние УВ на огнетушащую эффективность бинарных газоаэрозольных газовых систем при тушении идентичного тигля с н-гептаном. Для определения огнетушащей эффективности тернарной системы, состоящей из огнетушащего аэрозоля, газов $\left(\mathrm{CO}_{2}\right.$ или $\left.\mathrm{N}_{2}\right)$ и УВ, была сначала определена огнетушащая эффективность аэрозоля, полученного из АОС на основе идитола при действии 1 УВ. Результаты эксперимента с одинарной УВ показаны на графике на рис. 2, а с серией из 3-х УВ с частотой 10 Гц на 
графике на рис. 3. Эксперимент по определению огнетушащей эффективности проводили следующим образом: брали соответствующую массу АОС, сжигали ее в объеме камеры, перемешивали вентилятором газ и аерозоль для их равномерного распределения и задействовали генератор УВ, пропуская при этом одну или несколько УВ с со- ответствующей частотой. Значение давления одинарной УВ показаны на рис. 2.

Тепловую интенсивность излучения определяли прибором ПТП-01 на растоянии - 150 мм и для тигля с диаметром 30 мм получили значение теплового излучения в 4 кBт/м², в 60 мм 10 кВт/м² и для тигля в $100 \mathrm{~mm}-18$ кВт/м².

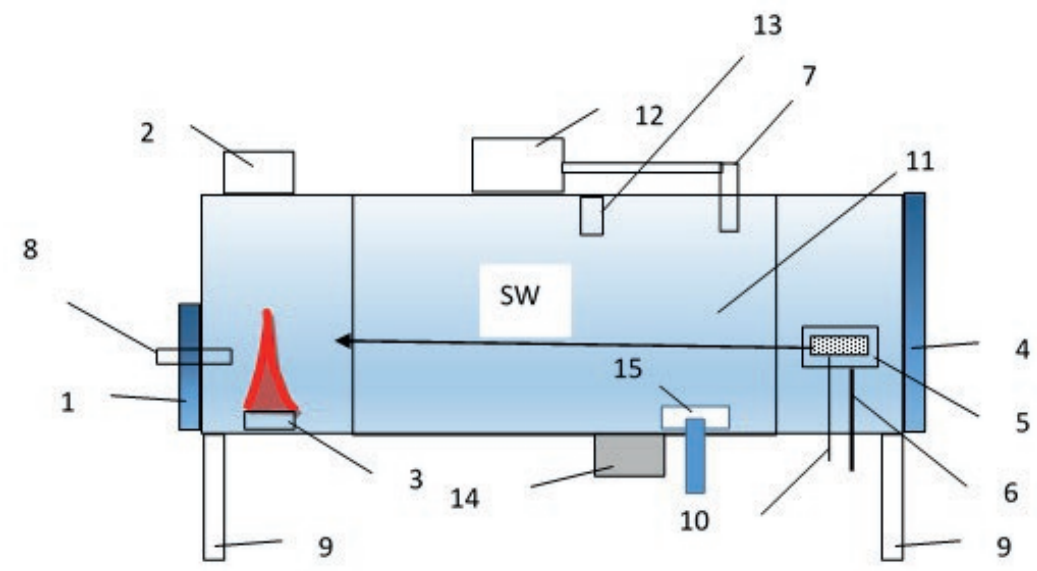

Рисунок 1. Экспериментальная установка для определения огнетушащей эффективности объемного огнетушащего вещества под действием ударной волны: 1. Люк для тигля. 2. Вентиляционное отверстие с вентилятором и задвижкой. 3. Тигель. 4. Люк.

5. Генератор ударных волн. 6. Крепления генератора ударных волн. 7. Патрубок для газа. 8. Датчик давления ВМР-180. 9. Стойки. 10. Электровоспламенитель АОС. 11. Смотровое окно. 12. Газовый счетчик. 13. Вентилятор. 14. Источник питания. 15. Воспламенитель АОС. Figure 1. The experimental setup for determining the extinguishing efficiency of the volume extinguishing agent under the impact of shock waves. 1. Hole for the crucible. 2. Vent with fan and valve. 3. Crucible. 4. Hole. 5. Shock-wave generator. 6. 4. The fastening of the shock wave generator. 7. Inlet for gas. 8. BMP 180 pressure sensor. 9. Stand. 10. Electric igniter of aerosol-forming mixture. 11. Observation window. 12. Gas meter. 13. Fan. 14. Power supply. 15. Igniter of aerosol-forming mixture Источник: Собственная разработка. Source: Own elaboration.

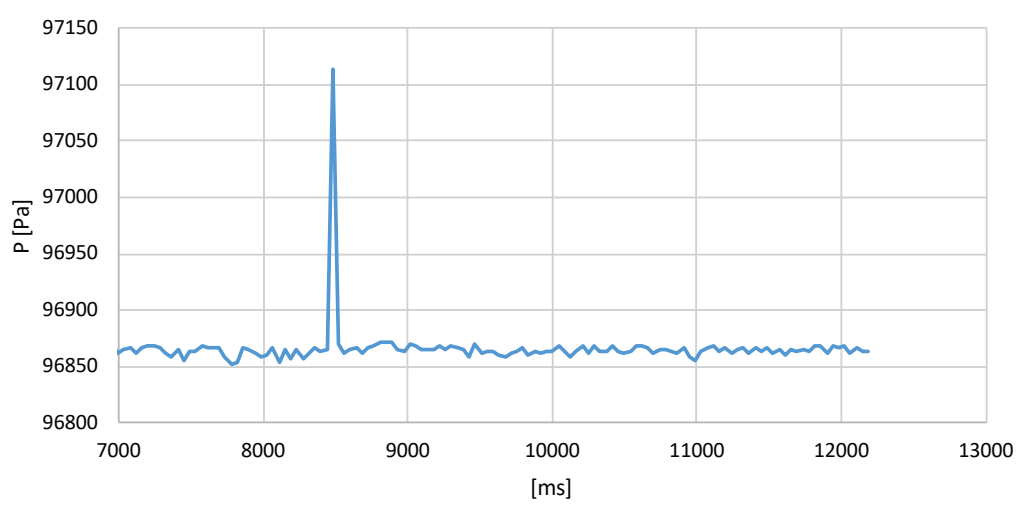

Рисунок 2. Увеличение давления при прохождении УВ с выходной мощностью одинарного УВ Р $\approx 240$ Па

Figure 2. The increase in pressure during the passage of a shock wave with an output force of a single SW P $\approx 240 \mathrm{~Pa}$ Источник: Собственная разработка.

Source: Own elaboration. 


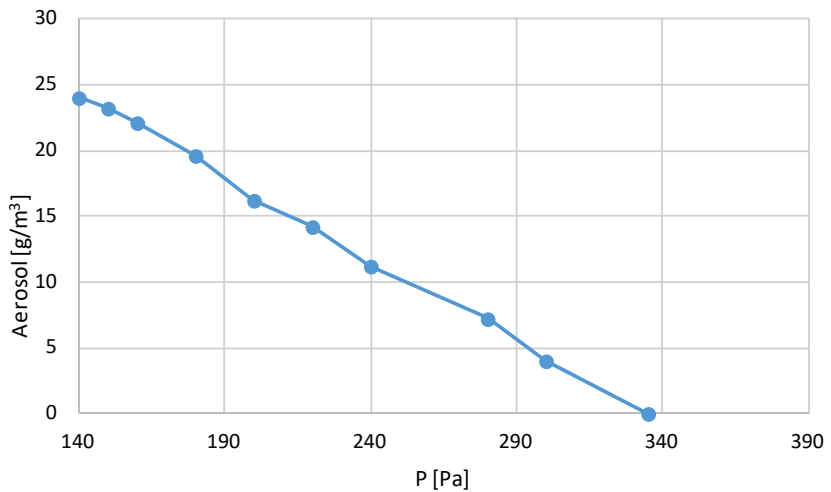

Рисунок 3. Зависимость огнетушащей эффективности аэрозоля от мощности одинарной ударной волны Figure 3. The dependence between the fire-extinguishing effectiveness of the aerosol and the force of a single shock wave Источник: Собственная разработка. Source: Own elaboration.

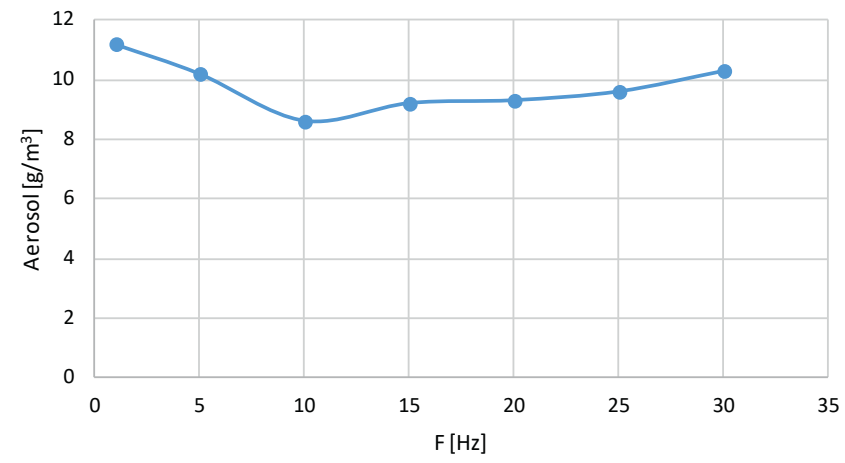

Рисунок 4. Зависимость огнетушащей эффективности аэрозоля от частоты воздействия ударной волны (серии по 3 УВ)

Figure 4. The dependence between the fire-extinguishing effectiveness of the aerosol and the frequency of the shock wave (series of 3 shock waves each) Источник: Собственная разработка.

Source: Own elaboration.

Как видно, при воздействии на ДПГ 1 ударной волны огнетушащая концентрация аэрозоля значительно снижается, что видно из графиков на рис. 3. При увеличении давления УВ огнетушащая концентрация аэрозоля падает с прямолинейной зависимостью и при достижении 240 Па уменьшается до 11,2 г/м³ (рис. 2). Максимальное снижение огнетушащей концентрации происходит при частоте УВ в 10 Гц (рис. 3). При этом снижение огнетушащей концентрации продолжается до 33 \%. Эти результаты совпадают с результами работ $[23,24]$.

Известно [27, 28, 29], что сам аэрозоль обладает достаточно высокой огнетушащей концентрацией за счет малых размеров (до 50 мкм) частиц. Учитывая, что УВ в аэрозольной среде подвергается значительной диссипации [30], то при значительных концентрациях аэрозоля ударная волна может сильно рассеиваться. Добавление газов до аэрозоля обеспечивает достижение двух важных целей - увеличение огнетушащей эффективности созданной бинарной системы $[10,11]$ и уменьшение в ней концентрации огнетушащего аэрозоля, что приводит к увеличению эффективного огнетушащего расстоянии УВ, вследствие уменьшения диссипации. Таким образом, добавка газов до аэрозоля приведет к уменьшению диссипации УВ в образованной среде и увеличению эффективного расстояния огнетушащего действия УВ и общей огнетушащей эффективности тернарной огнетушащей системы.

Далее было проведено определение огнетушащей эффективности тройных систем огнетушащий аэрозоль + газ флегматизатор $\left(\mathrm{CO}_{2}, \mathrm{~N}_{2}\right)+$ УВ при воздействии одинарной ударной волны. Результаты экспериментов показаны на рис. 5 и 6 .

Как видно из графиков при увеличении давления УВ огнетушащая концентрация аэрозоля и газа $\mathrm{CO}_{2}$ падает и оптимальным соотношением компонентов в тернарной огнетушащей системе при давлении во фронте УВ около

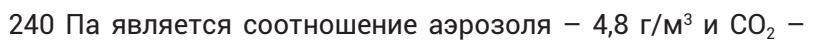
5,6 \%. Оптимальное соотношение принимаем исходя из условия, что давление УВ в самой дальней точке защищаемого объема обеспечит огнетушащее значение, исходя из параметров тушения тернарной системой: огнетушащий аэрозоль + газ + УВ. Для бинарной системы на основе $\mathrm{N}_{2}$ эти

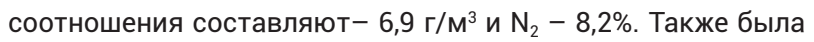
определена огнетушащая эффективность бинарной смеси огнетушащего аэрозоля и азота, получено соотношение аэрозоля $-7,8 г / \mathrm{M}^{3}, \mathrm{~N}_{2}-9,6 \%$. 


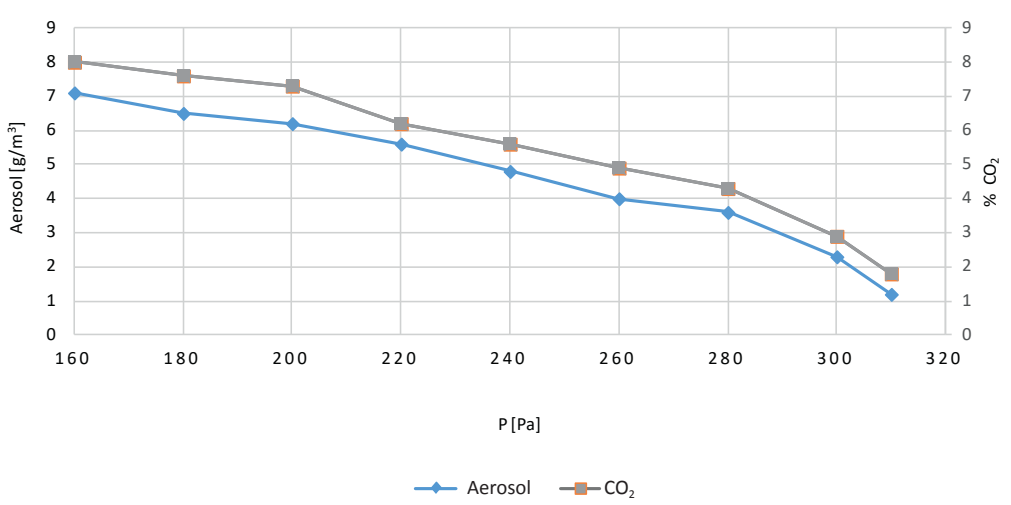

Рисунок 5. Зависимость огнетушащей эффективности бинарной смеси $\mathrm{CO}_{2}$ и аэрозоля от мощности одинарной ударной волны Figure 5. The dependence between the fire-extinguishing effectiveness of a binary mixture of $\mathrm{CO}_{2}$ and aerosol and a single shock wave Источник: Собственная разработка.

Source: Own elaboration.

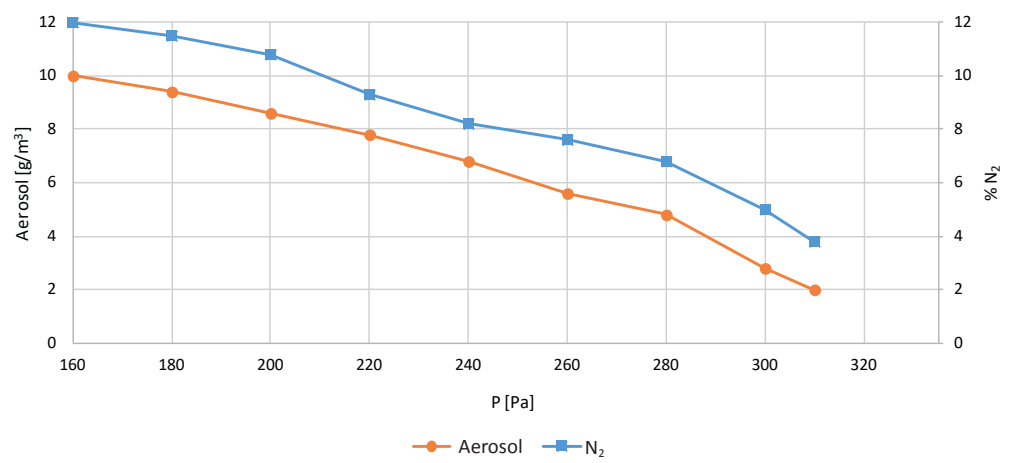

Рисунок 6. Зависимость огнетушащей эффективности бинарной смеси $\mathrm{N}_{2}$ и аэрозоля от мощности одинарной ударной волны Figure 6. The dependence between the fire-extinguishing efficiency of the binary mixture $\mathrm{N}_{2}$ and the aerosol and a single shock wave Источник: Собственная разработка.

Source: Own elaboration.

С целью определения времени и особенностей процесса тушения была проведена раскадровка процесса тушения (рис. 7) тернарной огнетушащей системой при следующих

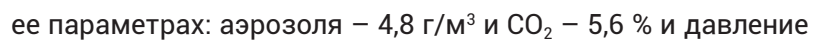
в 240 Па одинарной ударной волны.
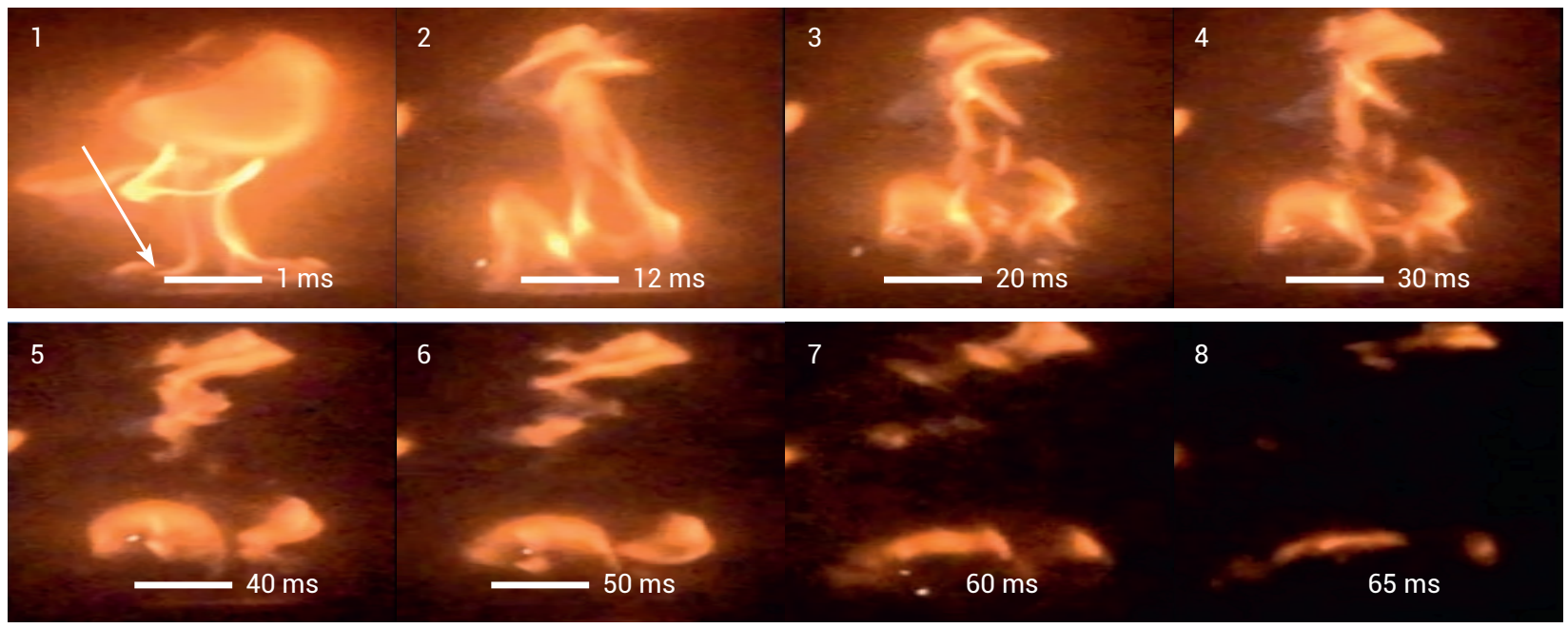

Рисунок 7. Раскадровка процесса тушения тернарной системой УВ ( Р $\approx 240$ Па), аэрозоль - $(4.8$ г/м³ $), \mathrm{CO}_{2}-(5.6 \%)$. Время тушения 65 мс Figure 7. Storyboard of the extinguishing process utilising a ternary system: SW ( $\mathrm{P} \approx 240 \mathrm{~Pa})$, aerosol $\left(4.8 \mathrm{~g} / \mathrm{m}^{3}\right), \mathrm{CO}_{2}(5.6 \%)$. Extinguishing time: $65 \mathrm{~ms}$ Источник: Собственная разработка.

Source: Own elaboration. 
Как видно из раскадровки (рис. 7), при тушении указанной системой пламя отрывается и фрагментируется на 40 мс (рис. 7, поз. 5), что значительно быстрее, чем в случае тушения самой УВ, когда время тушения составляет 350 мс. При этом, процесс отрыва происходит при минимальном давлении в 240 Па во фронте УВ. Потом пламя значительно фрагментируется и благодаря комбинированному действию УВ и газов [20] затухает на 65 мс (рис. 7, поз. 8). Уровень тигля на раскадровке (рис. 7) указан стрелкой.

Процесс тушения бинарной смесью с $\mathrm{N}_{2}$ происходит таким же образом как и в случае с $\mathrm{CO}_{2}$ при действии УВ с давлением в 240 Па. При этом пламя также гаснет вследствии отрыва и фрагментации из-за действия УВ. В результате тушение происходит за время несколько большее, чем при тушении $\mathrm{CO}_{2}$, и составляет $\approx 94$ мс.
Далее автор определил огнетушащую эффективность бинарной смеси аэрозоля на основе идитола с добавками газов $\mathrm{CO}_{2}$ и $\mathrm{N}_{2}$ при воздействии серий УВ с частотой 10 Гц на ДПГ в газоаерозольной системе. Одно из значений повышения давления в результате действия 3-х УВ показано на графике (рис. 8). При этом были получены результаты с огнетушащей концентрацией газов $\mathrm{CO}_{2}$ и $\mathrm{N}_{2}$ в указанных условиях, которые показаны на графике (рис. 9), а также показана зависимость огнетушащих концентраций бинарной смеси аэрозоля и $\mathrm{CO}_{2}$ от частоты воздействия серии 3-х ударных волн с Р(УВ) $\approx 240$ Па. На графике (рис. 10) показана зависимость огнетушащей эффективности бинарной смеси аэрозоля и $\mathrm{N}_{2}$ от частоты воздействия серии из 3-х УВ ударных волн с Р(УВ) $\approx 240$ Па.

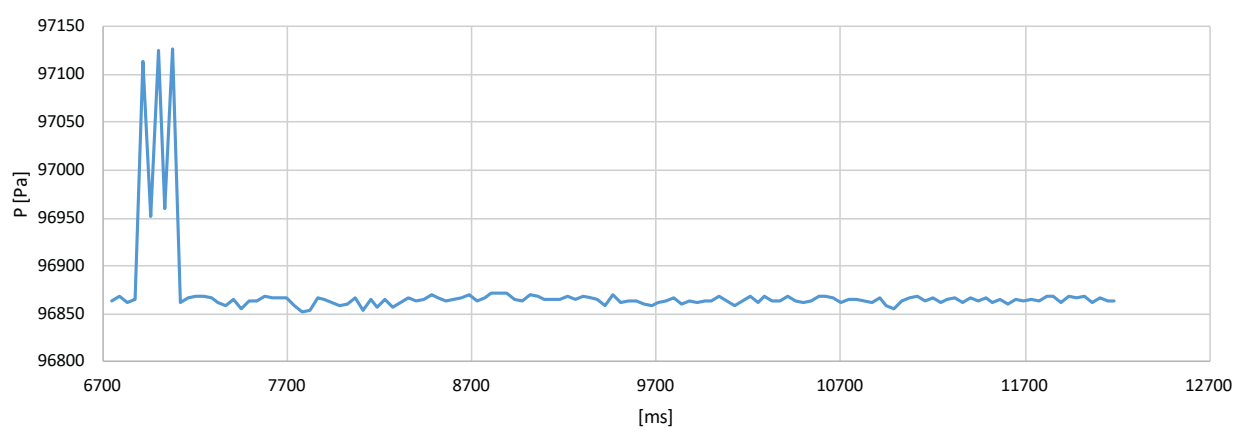

Рисунок 8. Увеличение давления при прохождении серии из 3-х УВ с частотой 10 Гц и мощностью $\mathrm{P} \approx 240$ Па Figure 8. The increase in pressure during the passage of a series of $3 \mathrm{SW}$ with a frequency of $10 \mathrm{~Hz}$ and force of $\mathrm{P} \approx 240 \mathrm{~Pa}$ Источник: Собственная разработка. Source: Own elaboration.

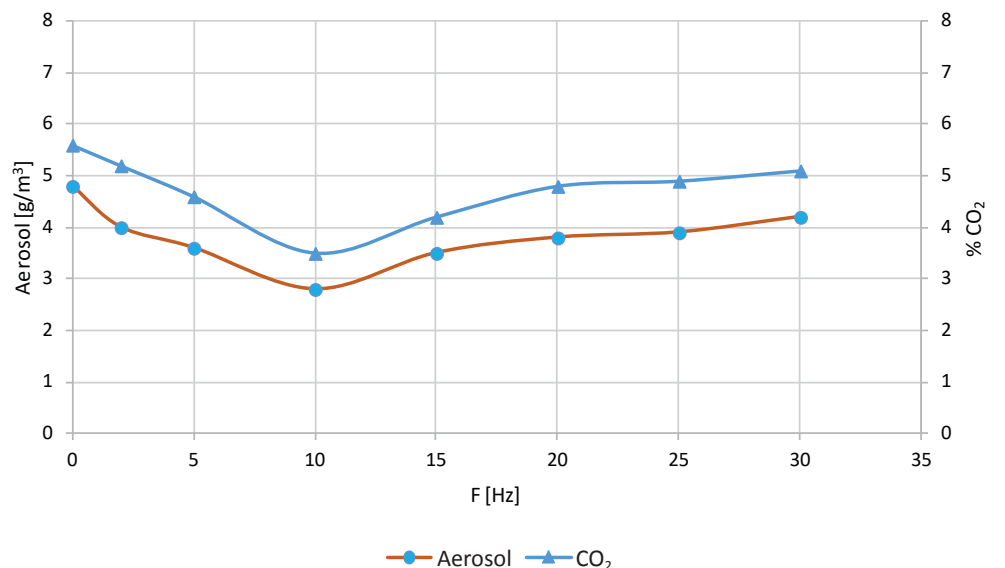

Рисунок 9. Зависимость огнетушащей эффективности бинарной смеси аэрозоля и $\mathrm{CO}_{2}$ от частоты воздействия серии 3-х ударных волн с Р $\approx 240$ Па Figure 9. The dependence between the fire-extinguishing effectiveness of a binary mixture of aerosol and $\mathrm{CO}_{2}$ and the frequency of the impact of a series of 3 shock waves with $\mathrm{P} \approx 240 \mathrm{~Pa}$ Источник: Собственная разработка. Source: Own elaboration. 


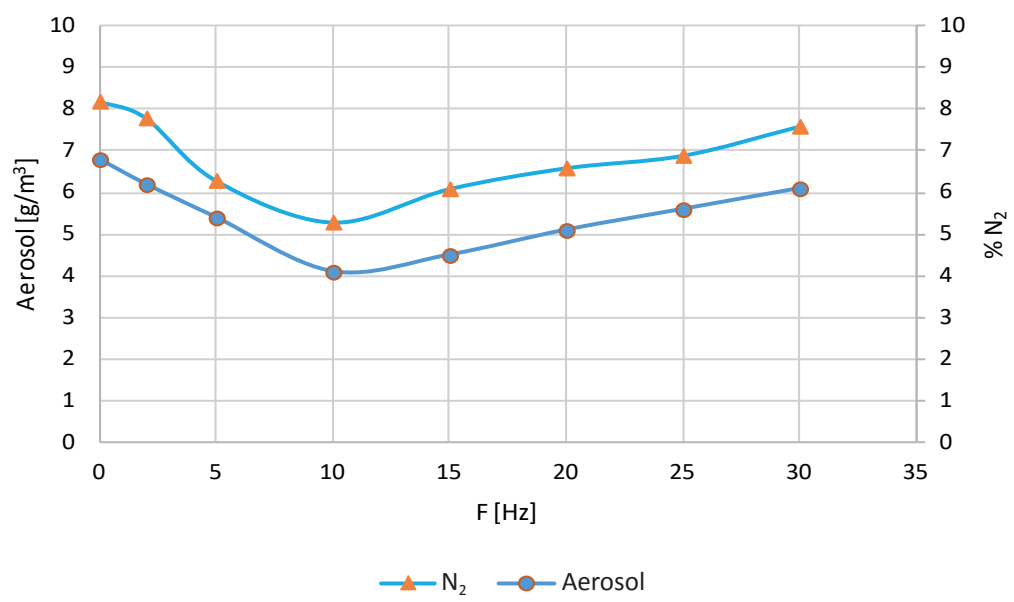

Рисунок 10. Зависимость огнетушащей эффективности бинарной смеси аэрозоля и $\mathrm{N}_{2}$ от частоты воздействия серии 3 -х ударных волн с $\mathrm{P} \approx 240$ Па Figure 10. The dependence of the fire-extinguishing effectiveness of a binary mixture of aerosol and $\mathrm{N}_{2}$ and the frequency of the impact of a series of 3 shock waves with $\mathrm{P} \approx 240 \mathrm{~Pa}$

Источник: Собственная разработка.

Source: Own elaboration.

Как видно из графиков (рис. 9 и 10) при частоте воздействия серий УВ в 10 Гц огнетушащая концентрация компонентов бинарной газоаерозольної смеси снижается до 2,8 \% и 3,5 г/M ${ }^{3}$ соответственно $\mathrm{CO}_{2}$ и аэрозоля. Для азота огнетушащие концентрации соответственно падают, для аэрозоля до 4,1 г/ $\mathrm{M}^{3}$ и до 5,3 \% для $\mathrm{N}_{2}$.
Таким образом, при применении тернарной системы: огнетушащий аэрозоль + газ разбавитель + действие серий УВ, во всех случаях наблюдалось значительное уменьшение огнетушащих концентраций аэрозоля и газов при воздействии УВ с частотой 10 Гц и давлением в 240 Па. Результаты эксперимента показаны на рис. 9 и на рис. 10.

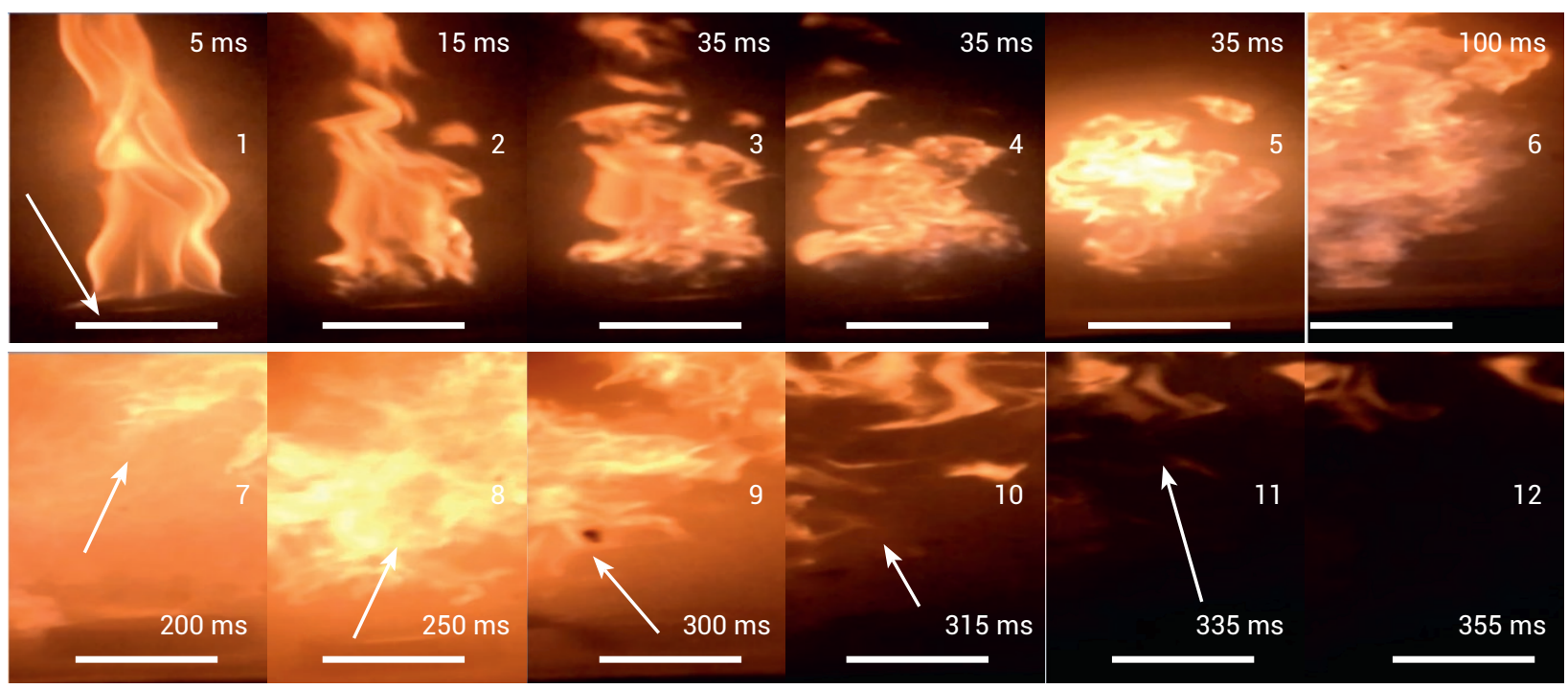

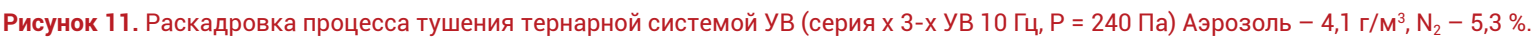
Время тушения - 55 мск

Figure 11. Storyboard of the extinguishing process utilising a ternary SW method (a series of three $10 \mathrm{~Hz} \mathrm{SW}, \mathrm{P}=240 \mathrm{~Pa}$ ) Aerosol $-4.1 \mathrm{~g} / \mathrm{m}^{3}$, $\mathrm{N}_{2}-5.3 \%$. Extinguishing time is $55 \mathrm{~ms}$ Источник: Собственная разработка. Source: Own elaboration.

Результаты раскадровки процесса тушения диффузионного пламени н-гептана тернарной системой аэрозоля, $\mathrm{CO}_{2}$ и сериями УВ при частоте 10 Гц показаны на раскадровке на рис. 11.

Раскадровка процесса тушения указанной тернарной системой показала, что пламя при одновременном действии ука- занных компонентов значительно турбулизируется, отрывается и при меньшем давлении во фронте УВ, чем в случае тушения в среде самого газа или аэрозоля. При этом после первой УВ заметно значительную турбулизацию пламени начиная с 5 до 100 мс (рис. 11, поз 1-6), но тушение пламени не происходит. Пламя 
находится на некотором расстоянии от тигля, как показано на рисунке 11 стрелками, до прохождения следующей ударной волны. Дальше на 200 мс (рис. 11, поз. 7) проходит следующая УВ, при этом пламя еще больше турбулизируется и отрывается от устья вытекания из тигля (тигель обозначен линией во всех позициях указан стрелкой на рис. 11, поз. 1).

При этом пламя значительно растягивается в пространстве и хаотично увеличивается в размерах в диапазоне времени между 200 и 300 мс (рис. 11, поз 7-9). Далее на 300 мс проходит 3-я УВ, которая еще больше относит пламя от тигля, после чего оно значительно фрагментируется и примерно через 55 мс гаснет (поз. 9-12).

\section{Обсуждение результатов работы}

Для подтверждения выдвинутых выше предположений про высокую огнетушащую эффективность комбинированной тернарной системы: УВ + огнетушащий газ + аэрозоль на пламя была проанализирована раскадровка процесса тушения при действии одинарной УВ с давлением в 240 Па с аэрозолем и газами $\mathrm{CO}_{2}$ и $\mathrm{N}_{2}$ на диффузионное пламя н-гептана. При раскадровке процесса тушения тернарной системой на основе $\mathrm{CO}_{2}$ (рис. 10) было обнаружено, что тушение пламени серий УВ происходит при давлении в фронте УВ в 240 Па, за 35 мс после прохождения последней УВ, что по времени меньше в 10 раз, чем при тушении самой только УВ (Р $\approx 350 \mathrm{Mc})$ без газоаерозоля.

Таким образом, в результате раскадровки можно увидеть значительную разницу при тушении одинарной УВ, когда пламя сразу по прохождении фрагментируется, рассеивается и тухнет, и серией УВ, когда пламя значительно турбулизуруется, немного растягивается, но тушения при этом не происходит. При воздействии на пламя серий из 3-х УВ можно сказать, что при этом происходит снижение огнетушащих концентраций компонентов смеси в диапазоне от 33 \% для газов и до 50 \% для аэрозолей в сравнении с исходными значениями индивидуальных концентраций компонентов смеси взятых для одинарной УВ.
Как видно из результатов экспериментов, влияние УВ приводит к значительному снижению огнетушащей концентрации бинарной смеси аэрозоля и газов - разбавителей. Раскадровка действия огнетушащей системы на ДПГ с ука-

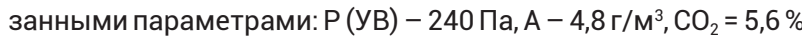
показала значительную разницу между поведением пламени при воздействии на него серий самой только УВ, а также УВ в среде газов или аэрозоля. При этом, можно сказать, что пламя значительно легче отрывается и время отрыва уменьшается с 335 мс при действии одной только УВ до 35 мс при тушении тернарной системой с серией УВ. Высокая эффективность тернарной огнетушащей системы (УВ + ГАЗ + АЭРОЗОЛЬ) объясняется комбинированным действием огнетушащих факторов компонентов тернарной огнетушащей системы. Кроме этого, огнетушащий аэрозоль и газ-разбавитель, как известно [12] являются синергентами, что приводит к значительно более высокой эффективности огнетушащей системы, чем традиционные средства пожаротушения. Свидетельством синергизма можна назвать значительное снижение огнетушащей концентрации аэрозоля, газов разбавителей и в некоторой мере мощности УВ при тушении ДПГ в 5, и более раз, в сравнении с индивидуальной огнетушащей концентрацией отдельных компонентов смеси, которые соответственно составляют, для гептана $\mathrm{C}_{7} \mathrm{H}_{16}$ Св $\left(\mathrm{CO}_{2}\right)=23 \%$, Св $(\mathrm{A})=22,5$ г/ $\mathrm{M}^{3}$ и Р $(\mathrm{УB})=215$ Па, (для тигля заданных параметров с тепловой излучательной способностю $\left.4 \mathrm{KBT} / \mathrm{M}^{2}\right)$.

Соответственно, если сравнить изменение концентрации объемных средств тушения, которые показаны в табл. 2, можно проследить четкую тенденцию к уменьшению их огнетушащей концентрации при их комбинированном действии вместе с УВ. Таким образом, имеем несколько вариантов огнетушащих систем с УВ, в которых огнетушащая концентрация объемных средств пожаротушения - газа, аэрозоля и их смеси - обобщены. Экспериментальные и литературные данные приведены в таблице 3.

Таблица 3. Сравнительная таблица огнетушащей эффективности систем с ударной волной

Table 3. Comparative table of the fire-extinguishing effectiveness of various systems with the shock wave

\begin{tabular}{|c|c|c|c|c|c|}
\hline $\begin{array}{l}\text { Влияние УВ (одинарная, серии) / } \\
\text { The impact of SW (single, series) }\end{array}$ & $\begin{array}{c}\text { Давление УВ [Па] } \\
\text { Pressure SW [Pa] }\end{array}$ & $\begin{array}{l}\text { Тепловая мощность пламени [кВт/м²] } \\
\text { Thermal power of the flame }\left[\mathrm{kW} / \mathrm{m}^{2}\right]\end{array}$ & $\mathrm{CO}_{2}, \%$ & $\mathrm{~N}_{2}, \%$ & $\begin{array}{c}\text { Аерозоль }\left[\mathrm{r} / \mathrm{m}^{3}\right] / \\
\text { Aerosol }\left[\mathrm{g} / \mathrm{m}^{3}\right]\end{array}$ \\
\hline одинарная УВ / single SW & 215 & 4 & - & - & - \\
\hline одинарная УВ / single SW & 180 & 4 & 5,1 & - & - \\
\hline одинарная УВ / single SW & 180 & 4 & - & 10,2 & \\
\hline одинарная УВ / single SW & 180 & 4 & - & - & 10,3 \\
\hline серии УВ (10 Гц) / SW series $(10 \mathrm{~Hz})$ & 172 & 4 & - & - & - \\
\hline серии УВ (10 Гц) / SW series $(10 \mathrm{~Hz})$ & 172 & 10 & 4,8 & - & - \\
\hline серии УВ (10 Гц) / SW series $(10 \mathrm{~Hz})$ & 170 & 10 & - & 10,8 & - \\
\hline серии УВ (10 Гц) / SW series $(10 \mathrm{~Hz})$ & 170 & 10 & - & - & 8,2 \\
\hline одинарная УВ / single SW & 240 & 18 & 4,9 & - & 5,6 \\
\hline одинарная УВ / single SW & 240 & 18 & - & 8,2 & 6,8 \\
\hline серии УВ (10 Гц) / SW series $(10 \mathrm{~Hz})$ & 240 & 18 & 3,5 & & 2,8 \\
\hline серии УВ (10 Гц) / SW series $(10 \mathrm{~Hz})$ & 240 & 18 & & 5,3 & 4,1 \\
\hline
\end{tabular}

Источник: Собственная разработка.

Source: Own elaboration. 
Исходя из анализа обобщенных данных, приведенных в таблице, при действии одинарной и серий УВ на пламя н-гептана видно, что ее воздействие на пламя приводит к значительному повышению огнетушащей эффективности и, как видно из таблицы, зависит от тепловой мощности пламени. Так при тепловой мощности излучения 4 кВт/м ${ }^{2}$ и одинарной УВ с давлением в фронте $\approx 180$ Па, как видим из таблицы, огнетушащая концентрация $\mathrm{CO}_{2}$ уменьшается до $5,1 \%$ Использование серий УВ с частотой в 10 Гц приводит к дальнейшему уменьшению огнетушащей концентрации и даже при большем размере пламени $(10$ кВт/м²) наблюдается уменьшение огнетушащей концентрации $\mathrm{CO}_{2}$ до 4,8 при почти одинаковом давлении во фронте УВ в $\approx 180$ Па. Дальнейшее увеличение размеров пламени $(18$ кВт/м²) тянет за собой увеличение огнетушащего давления во фронте УВ до 240 Па, но огнетушащая концентрация для $\mathrm{CO}_{2}$ и аэрозоля остаются почти на прежнем уровне. Составляет примерно

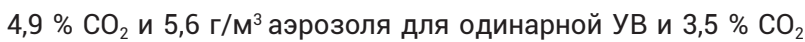

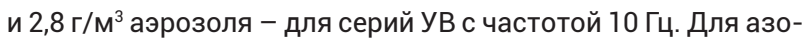
та также наблюдается уменьшение до 8,2 $\mathrm{N}_{2}$ и 6,8 г/M $\mathrm{M}^{3}$ аэ-

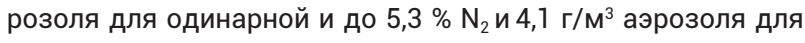
серий УВ.

Таким образом, комбинированое использование огнетушащего газа, аэрозоля и серий УВ с частотой в 10 Гц приводит к значительному повышению огнетушащей эффективности такой системы, что видно на примере тушения пламени н-гептана заданных параметров.

\section{Вывод}

В работе теоретически обоснована и экспериментально подтверждена возможность значительного повышения огнетушащей эффективности бинарной смеси огнетушащего аэрозоля и газов $\mathrm{CO}_{2}$ или $\mathrm{N}_{2}$ при действии на пламя н-гептана серии ударных волн с частотой 10 Гц в их среде в условиях камеры. Значительное повышение огнетушащей эффективности, заявленной тернарной огнетушащей системы, вероятно (из выводов автора) за счет синергизма между компонентами системы. При этом определено, что в бинарной смеси, огнетушащая концентрация аэрозоля уменьшается до 8 раз, а для газов до 4,6 раза, относительно их индивидуальных огнетушащих концентраций при воздействии на диффузионное пламя н-гептана серий из 3-х ударных волн с частотой 10 Гц и давлением около 240 Па. Также автором экспериментально определено, что общим результатом комбинированного действия ударной волны, огнетушащих газов и аэрозоля будет значительное уменьшение времени тушения диффузионого пламени н-гептана, в сравнении с временем тушения пламени н-гептана только ударными волнами.

Экспериментально определены особенности тушения дифузионого пламени н-гептана в условиях специальной камеры, предложенной комбинированной огнетушащей тернарной системой, которые заключаются в том, что время начала фрагментации пламени значительно уменьшается после прохождения серии ударных волн, после чего пламя отрывается и фрагментируется, при значительно меньших концентрациях огнетушащих веществ, чем их индивидуальные, а также при действии одинарных ударных волн, что приводит к более быстрому отрыву и тушению.

Таким образом, предложенная тернарная огнетушащая система в условиях экспериментальной камеры обеспечивает быстрое и эффективное тушение диффузионного пламени н-гептана и может быть основой нового способа тушения пожаров класов A, B, C, E.

\section{Литература}

[1] United Nation Environmental Program (UNEP), Montreal Protocol on Substances that Deplete the Ozone Layer, Report of the Halon Fire-extinguishing Agents Technical Options Committee, [electr. doc.] http://ozone.unep.org/en/information-material [accessed: 11.03.2017].

[2] Amin M.B., Husain T., Kuwait oil fires - air quality monitoring, „Atmospheric Environment" 1994, 28(13), 2261-2276, [electr. doc.] http://www.researchgate.net/publication/248341283 [accessed: 11.03.2017].

[3] Mannan M.S., A technical analysis of the buncefield explosion and fire, "Symposium series. Hazards XXI" 155(2009) http://www. ichemeoncampus.org/ /media/Documents/Subject\%20Groups/ Safety_Loss_Prevention/Hazards\%20Archive/XXI/XXI-Paper-094. pdf [accessed: 11.04.2017].

[4] Pozhar na neftebaze v Vasilkovskom rayone, https://uk.wikipedia. org/wiki/Пожежа_на_нафтобазі_у_Васильківському_районі

[5] Chattaway A., Dunster R.G., Spring D.J., Way M., Evaluation of Alternative Agents for Suppression Fuel Spray Explosions in Military Vehicle Crew Compartments, Halon Options Technical Working Conference, Albuquerque, New Mexico 1999, 27-33, 45-53.

[6] Smigielski G., Dygdała R., Serejko G., Kaczorowski M., Estimation size of aerosol droplets produced by explosion, „Przegląd elektrotechniczny" 2016, 11,91-94, doi:10.15199/48.2016.11.23.

[7] Korobeinichev O.P., Shmakov A.G., Chernov A.A., Bol'shova T.A., Shvartsberg V.M., Kutsenogii K.P., Makarov V.I., Fire Suppression by Aerosols of Aqueous Solutions of Salts, "Combustion, Explosion, and Shock Waves" 2010, 46(1), 16-20, doi:10.1007/s10573-0100003-y.

[8] Balanyuk V.M., Grimalyuk B.T., Doslidzhennya vplivu inertnikh gazovikh rozridzhuvachiv na efektivnist vognegasnikh ayerozoliv, „Pozhezhna bezpeka" 2004, 5, 18-24.

[9] Balanyuk V.M., Zhurbinskiy D.A., Lin A.S., Vliyaniye vida aerozolobrazuyushchikh soyedineniy na osnove soley kaliya i dobavok inertnykh gazov na flegmatiziruyushchuyu effektivnost aerozolya, „Pozharnaya bezopasnost: sb. nauchn. rabot." 2013, 22, 7-11.

[10] Balanyuk V.M., Zhurbinskiy D.A., Phlegmatisation of flammable gas mixtures by aerosol sprays, BiTP Vol. 32 Issue 4, 2013, pp. 53-58, doi:10.12845/bitp.32.4.2013.6.

[11] Garasymyuk O.I., Balanyuk V.M., Pastukhov P.V., Nekotoryye aspekty povysheniya effektivnosti aerozolno-poroshkovogo pozharotusheniya, „Vestnik Kokshetauskogo tekhnicheskogo instituta" 2016, (22)2, 39-49.

[12] Lott J.L., Christian S.D., Sliepcevich C.M., Tucker E.E, Synergism Between Chemical and Physical Fire-Suppressant Agents, "Fire Technology" 1996, 323, 260-271, doi: 10.1007/BF01040218. 
[13] Saito N., Saso Y., Ogawa Y., Otsu Y., Kikui H., Fire Extinguishing Effect of Mixed Agents of Halon 1301 and Inert Gases, "Fire Safety Science" 1997, 5, 901-910, doi:10.3801/IAFSS.FSS.5-901.

[14] Balanyuk V.M., Kozyar N.M., Garasymuyk O. I., Study of fire-extinguishing efficiency of environmentally friendly binary aerosolnitrogen mixtures, "Eastern-european journal of enterprise" 2016, 3/10(71), 4-12, doi: 10.15587/1729-4061.2016.72399.

[15] Balanyuk V.M., Specific Nature of Phlegmatizing Air-Heptan Mixture using aerosol and Nitrogen Binary Mixture, BiTP Vol. 44 Issue 4, 2016, pp. 139-149, doi:10.12845/bitp.44.4.2016.11.

[16] Balanyuk V.M., Kozyar N.M., Garasim'yuk O.I., Zastosuvannya gazo-ayerozolno-poroshkovikh vognegasnikh sumishey dlya zakhistu vid zapalyuvalnikh sumishey, "Scientific Journal ScienceRise" 2016, 5/2(22), 10-14, doi: 10.15587/2313-8416.2016.69333.

[17] Balanyuk V.M., Kozyar N.M., Garasim'yuk O.I., Lozinskiy A.T., Vpliv dobavok $\mathrm{CO}_{2}$ na vognegasnu efektivnist binarnoï ayerozolno-gazovoï sumishi, „Pozhezhna bezpeka: zb. nauk. pr." 2016, 28, 6-12.

[18] Balanyuk V.M., Garasim'yuk O.I., Lin A.S., Vpliv na flegmatizuvalnu efektivnlst aerozolyu dobavok $\mathrm{CO}_{2}, 16$ Vseukr. konf. ryatuvalniklv, 23-24.09.2014, 27-29.

[19] Balanyuk V.M., Kombinovani vognegasni sistemi na osnovi udarnoï khvili ta gazovoï ob'emnoï vognegasnoï rechovini, „Pozhezhna bezpeka: zb. nauk. pr." 2016, 29, 6-12.

[20] Balanyuk V.M., Extinguishment of $n$-heptane diffusion flames with the shock wave, BiTP Vol. 42 Issue 2, 2016, pp. 103-111, doi: 10.12845/bitp.42.2.2016.10.

[21] Balanyuk V.M., Pozhezhogasinnya seriyami udarnikh khvil, „Problemy pozharnoy bezopasnosti" 2016, 40, 26-34.

[22] Balanyuk V.M., Increasing the Effectiveness of Fire Extinguishing using a Gas Method which Applies a Shock Wave, BiTP Vol. 43 Issue 3, 2016, pp. 81-94, doi: 10.12845/bitp.43.3.2016.8.

БАЛАНЮК ВЛАДИМИР МИРЧЕВИЧ - Кандидат теХнических наук, доцент. В 2007 году защитил диссертацию по специальности пожарная безопасность. С 2007 года работает на кафедре процессов горения и химии Львовского государственного университета безопасности жизнедеятельности. Область научных интересов: теоретические и экспериментальные исследования процессов горения, аэрозольные, порошковые, газовые, комбинированные средства пожаротушения, огнезащитные покрытия для древесины и металлов.
[23] Balanyuk V.M., Kopistinskiy Yu.O., Lavrenyuk O.I., Viznachennya efektivnosti gasinnya vognegasnoyu ayerozolnoyu rechovinoyu v umovakh zastosuvannya gazovikh udarnikh khvil, „Pozhezhna bezpeka : zb. nauk. pr." 2012, 21, 23-27.

[24] Kopistinskiy Yu.O., Doslidzhennya vplivu udarnoï khvili na vognegasnu efektivnist ayerozolevoï rechovini neorganichnikh soley kaliyu, „Naukoviy visnik UkrNDIPB» 2011. № 2 (24) - 2012. - №21. C. 23-27.

[25] Balanyuk V.M., Kopistinskiy Yu.O., Boyko T.B., Zhurbinskiy D.A., Vikoristannya udarnih hvil pri gasinni difuziynogo polum'ya vognegasnimi aerozolyami, „Pozhezhna bezpeka: teorya i praktika” 2014, 18, 32-37.

[26] BMP180 Data sheet [electr. doc.] https://www.adafruit.com/datasheets/BST-BMP180-DS000-09.pdf [accessed: 11.04.2017].

[27] Fogel'zang A.E., Vasil'ev V.V., Sinditskii V.P. et. al., Effektivnye sistemy pozharotusheniya na osnove porokhov i spetsial'nykh tverdykh topliv (Efficient Systems for Fire-Fighting on the Basis of Powders and Special-Purpose Propellants), NPO "InformTEl", Moscow 1991, 30-31.

[28] Zhukov B.P., Denisyuk A.P., Shepelev Y.G. et. al., Combustion of Fire-Extinguishing Powders Based on Potassium Nitrate, "Doklady Physical Chemistry" 2002, 382, 35, doi:10.1023/ A:1014447212689.

[29] Brooks J., Berezovsky J., O'Dwyer M., Aerosol fire suppression for high rise structural applications via aircraft distribution using $\mathrm{Me}$ talstorm technologies, [in:] NIST Special Publication 984, Halon Options Technical Working Conference, 12th Proceedings. HOTWC 2002, Albuquerque, NM, 1-8.

[30] Nakoryakov V.E., Pokusayev B.G., Shreyber I.R., Rasprostraneniye voln v gazo- i parozhidkostnykh sredakh, In-t teplofiziki, Novosibirsk 1983, 237. 


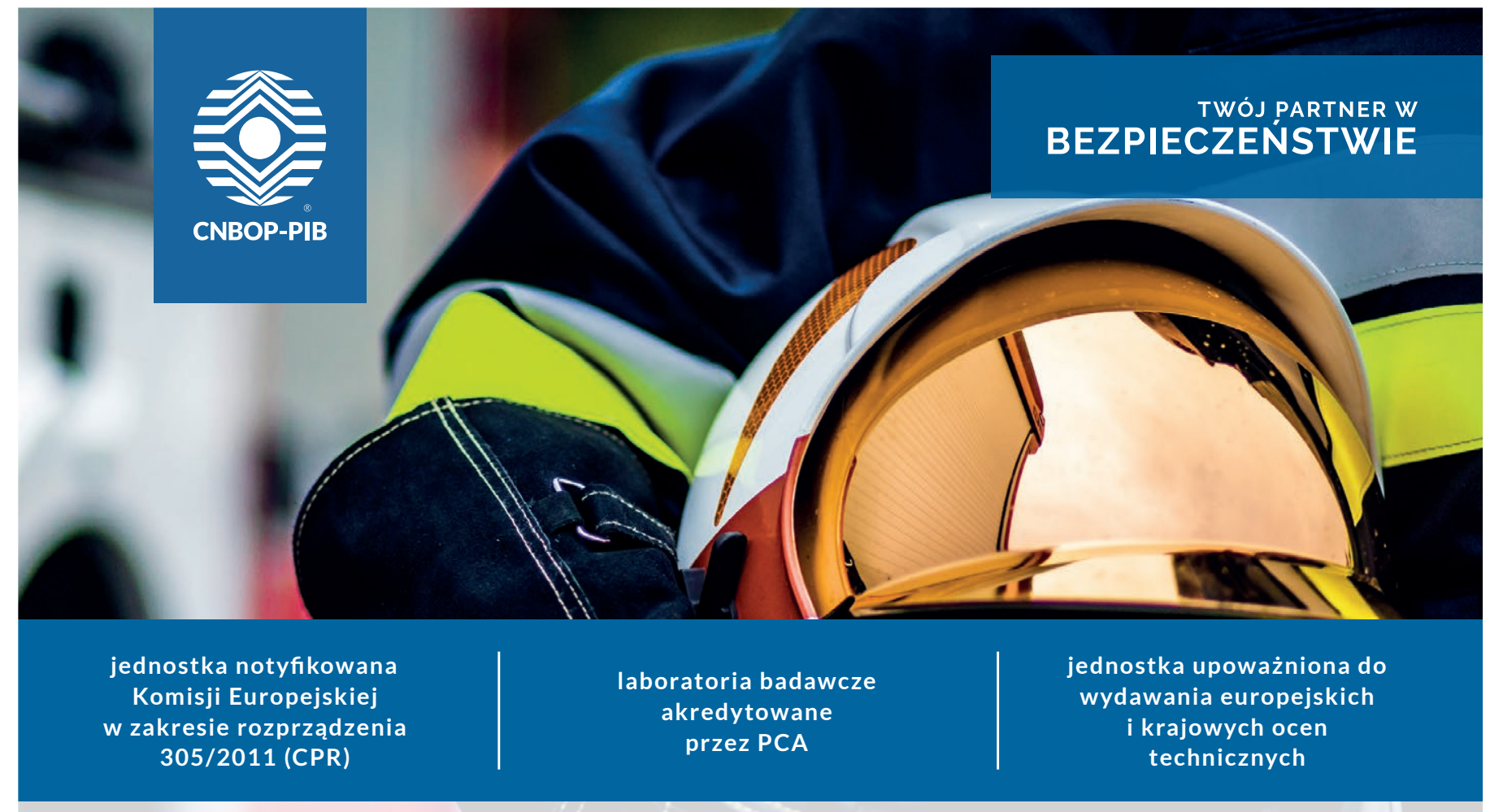

\section{$4 \sqrt[5]{\text { lat doświadczenia }}$}

DOPUSZCZENIA WYROBÓW

użytkowanych w ochronie przeciwpożarowej

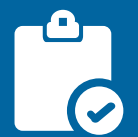

EUROPEJSKIE I KRAJOWE

OCENY TECHNICZNE

stałych urządzeń ppoż.

kabli zasilających, sterujących

i komunikacyjnych

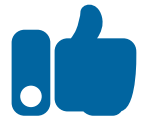

TESTOWANIE

WYROBOWW INNOWACYJNYCH

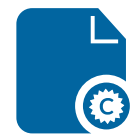

EUROPEJSKA

I KRAJOWA

CERTYFIKACJA

wyrobów budowlanych

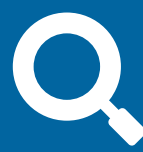

BADANIA

sprzętu oraz wyposażenia

jednostek ochrony ppoż.

stałych urządzeń gaśniczych

chemiczne i pożarowe

procesów spalania i wybuchowości

systemów i automatyki ppoż.

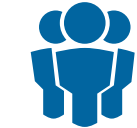

SZKOLENIA

z zakresu ochrony

przeciwpożarowej

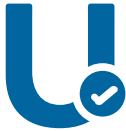

CERTYFIKACJA

PODMIOTOW

ŚWIADCZACYCH USŁUGI

w ochronie przeciwpożarowe

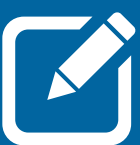

CERTYFIKACJA DOBROWOLNA

wyrobów

do ochrony

przeciwpożarowe

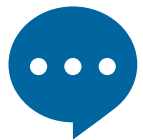

OPINIE I EKSPERTYZY TECHNICZNE 